\title{
Accounting policies in corporate governance practice and their impact on the financial position and business performance of company
}

\section{Računovodstvene politike u praksi korporativnog upravljanja i njihov uticaj na finansijski i prinosni položaj preduzeća}

\author{
Jelena Raičevića*, Jelena Filipov ${ }^{\mathrm{b}}$ \\ ${ }^{a}$ Academy of Professional Studies South Serbia, Business School Blace, Serbia \\ ${ }^{\mathrm{b}}$ University of Priština in Kosovska Mitrovica, Faculty of Economy Priština in Kosovska \\ Mitrovica, Serbia
}

\begin{abstract}
The primary role of financial statements is to provide information to users, both internal and external, to make business decisions. The preparation of financial statements includes a number of methods and procedures that have different effects on the values reported in the financial statements. The domain of accounting policies is precisely those methods and procedures, in fact rules related to the recognition and valuation of balance sheet items, as well as the preparation of financial statements. The choice of accounting policies achieves objectives that are mainly oriented towards the financial result and financial position of the reporting entity. The responsibility for the choice of accounting policies belongs to the management of the company. Their adequate choice by the management leads to a realistic view of the financial and profitable position of the company, as well as business success. The impact of applied accounting policies on the performance of companies is shown in a study conducted in companies in the Republic of Serbia, which showed differences in individual balance sheet items in groups of companies depending on the applied accounting policy.
\end{abstract}

Keywords: financial statements, accounting policies, financial result.

Sažetak: Primarna uloga finansijskih izveštaja je pružanje informacija korisnicima, kako internim tako i eksternim za donošenje poslovnih odluka. U pripremu finansijskih izveštaja uključene su brojne metode i postupci koji imaju različit uticaj na vrednosti iskazane u finansijskim izveštajima. Domen delovanja računovodstvenih politika su upravo te metode $i$ postupci, odnosno pravila vezana za priznavanje $i$ vrednovanje bilansnih pozicija, kao $i$ sastavljanje finansijskih izveštaja. Izborom računovodstvenih politika postižu se ciljevi koji su

*Corresponding author

E-mail address: glisictfl@gmail.com

This is an open access paper under the license cc) (1) () 
uglavnom orijentisani na finansijski rezultat i finansijski položaj izveštajnog entiteta. Odgovornost za izbor računovodstvenih politika pripada menadžmentu preduzeća. Njihov adekvatan izbor od strane menadžmenta dovodi do realnog prikaza finansijskog i prinosnog položaja preduzeća, kao i uspešnost poslovanja. Uticaj primenjenih računovodstvenih politika na performanse preduzeća, prikazan je u istraživanju koje je sprovedeno u preduzećima $u$ Republici Srbiji, koje je pokazalo razlike u pojedinim bilansnim pozicijama u grupama preduzeća u zavisnosti od primenjene računovodstvene politike.

Ključne reči: finansijski izveštaji, računovodstvene politike, finansijski rezultat.

\section{Introduction}

Both external and internal users are interested in information on the financial and overall position of the company contained in the financial statements as a product of the financial reporting process. Accordingly, the information presented must be credible, relevant, comparable, timely and understandable, so that users of financial statements can make quality business decisions based on it.

The quality of the content of financial statements largely depends on the chosen accounting policies. They are defined as specific postulates, principles and methods chosen by the company's management for the preparation and presentation of financial statements. Their choice affects the treatment of balance sheet items, which is reflected in the financial and profitable position of the company.

The paper will discuss the importance of the choice of accounting policies and their impact on the performance of specific companies. We will also point out the differences in the size of significant balance sheet positions of companies in the Republic of Serbia covered by the research, depending on the applied accounting policy.

\section{Basic characteristics of accounting policies}

Financial reports are the primary source of information for internal and external users that allow them to view the financial performance of the company, the assessment of management in the segment of resource management, as well as forecasting the future development of the company. Also, information from financial statements is the starting point for users in the business decision-making process.

The financial statements are the final product of the accounting information system and different methods and procedures are included in their preparation, which have different effects on the values stated in the financial statements. The choice of these methods and procedures is the domain of accounting policies. The quality of financial statements depends on the accounting policies chosen. By internal act, management selects and implements accounting policies for the preparation of financial statements for external users.

According to IAS 8 - Accounting Policies, Changes in Accounting Estimates and Errors, accounting policies are defined as "specific principles, bases, conventions, rules and practices applied by an entity in preparing and presenting financial statements" (International Financial Reporting Standards Foundation, 2017). Also, 
Accounting policies in corporate governance practice and their impact on the financial position and business performance of company

accounting policies can be defined as "specific accounting bases assessed by economic entities as the most appropriate for their circumstances, and adopted with the aim of preparing and presenting financial statements" (Britton \& Waterston, 1999, p. 50). Accounting policies are specific principles and rules related to the recognition and measurement of balance sheet items and the preparation and presentation of financial statements. It should be emphasized that accounting policies were not created with the obligation to apply International Accounting Standards, but have existed to a greater or lesser extent, ever since the financial statements were prepared and presented to their users in accordance with the Commercial Law.

With the advent of International Accounting Standard 1 - Presentation of Financial Statements for the first time there is an obligation to clearly define and disclose all applicable accounting policies. This obligation arises from the view that users of financial statements must be informed of the basics of their preparation in order to gain better insight into the company's business objectives.

According to IAS 1 - Presentation of Financial Statements, the following areas of accounting policies are covered (Brkanić, 2002, p. 95):

1. Management, business policy and accounting policies are closely interrelated and directed towards the common goal of preserving the financial strength and economic and production potential of the company. Accounting policies are considered an instrument for achieving the business policy of the company, aimed at achieving the general and specific goals of the company as a whole.

2. The Law on Accounting, in accordance with IAS and IFRS, prescribes the adoption of internal regulations in the form of a legal act. This legal act has the force of internal law, it is passed by the appropriate governing body in the company in accordance with the competencies defined by the statute of the company, it specifically defines the accounting policies and areas and criteria for their operation. The company's management must know and understand the basic accounting principles, methods and ethical accounting codes, in order to choose methods and procedures in cooperation with professional accounting staff that will most realistically show the financial position, change of financial position and business success in the current business conditions.

IAS 8 - Accounting Policies, Changes in Accounting Estimates and Errors, has been in force since 01.01.2005. The standard applies to (Petrović, 2011, p. 413).:

- in selecting and applying accounting policies,

- in accounting for the effects of changes in accounting policies,

- in accounting for the effects of changes in accounting estimates,

- in correcting errors from the previous period.

A very important issue is the recognition and valuation policies of balance sheet items. Recognition policies are quite rigorous and leave no room for alternatives as valuation policies. They come down to the question of when an item (transaction) is recognized as an asset, liability, expense or income. The recognition of an asset or liability item 
is based on the assumption that economic benefits will flow from it or that its value is reliably measurable. Revenue recognition implies an objectively measurable increase in capital that is reflected in an increase in assets or a decrease in liabilities. Expenses are recognized if there is an objectively measurable decrease in equity, ie a decrease in assets or an increase in liabilities.

Valuation policies under IAS and IFRS provide much greater choice. They are used to determine the amount assigned to an accounting item or position in the financial statements. They can be divided into measurement and evaluation policies. By measuring, the mentioned amounts are determined without making any assessment, on the basis of precise data (documented data such as amounts from invoices). Accounting estimates involve estimating the amount of an item in the financial statements in the absence of an accurate measurement.

It is necessary to harmonize the accounting policies with the business policy of the company, whose primary goals are "achieving maximum profit while providing liquidity and business continuity in the long run" (Todorović, 2012, p. 107).

\section{The importance of accounting policies for the preparation and presentation of financial statements}

Given that different users (business owners, creditors, employees, the general public, etc.) are interested in the information contained in the financial statements, managers have the greatest interest in the financial statements of the business entity to show the best results. In that sense, the responsibility for the application of generally accepted financial reporting standards as well as the quality of the implementation of accounting policies lies with the management of the company.

The company's management must know and understand the basic accounting principles, methods and ethical accounting codes, in order to choose methods and procedures in cooperation with professional accounting staff that will most realistically show the financial position, change of financial position and business success in the current business conditions (Brkanić, 2002, p. 95).

The process of choosing accounting policies is "team work in which the accountant, finance manager, procurement manager, sales manager, production manager, as well as representatives of other entity functions" participate (Todorović, 2012, p. 107). The objectives to be achieved by accounting policies may be different, but are mainly related to the impact on the financial result and financial position of the reporting entity. The impact of the chosen accounting policy on the financial statements depends on several factors (Žager \& Žager, 1999, p. 84):

- the share of a particular position in the total structure of assets, liabilities, income or expenses,

- characteristics of the chosen method,

- the observed time period and other influences.

The management of the company, as a governing body, with its powers and interests, and in accordance with the set goals of the company, creates a process of financial 
Accounting policies in corporate governance practice and their impact on the financial position and business performance of company

reporting in a given business entity. The responsibility of management is to compile high quality and transparent financial statements with the aim of presenting objective and comparable financial results and financial condition of the business entity for a certain period of time.

Every legal entity has the obligation to disclose selected and applied accounting policies (published rules and principles are published in the Notes to the financial statements). "When deciding whether to disclose a specific accounting policy, management analyzes whether it would help users understand the way in which business changes and events are presented in the statement of results and financial position" (Medojević, 2005, p. 41). Criteria for the selection of accounting policies are (Mitrović, 2013, p. 71):

- prudence (introduction of a certain degree of prudence in estimation revenues should not be overestimated, and expenses and liabilities underestimated, inventories should not be overestimated or underestimated, as this results in hidden gains or losses in business);

- essence above form (business events should be presented in accordance with their economic essence, and not exclusively their legal form);

- material significance (financial statements should include all items that deserve to be considered in accounting policy).

An economic entity consistently selects and applies its "accounting policy for similar transactions, other events and circumstances" unless a particular standard specifically requires categorization of items for which different policies would be appropriate, in which case the appropriate accounting policy is consistently selected and applied for each category (Republic of Serbia, Ministry of Finance, 2019).

Due to the existence of different accounting policies, their choice is "the result of an assessment in order to objectively and truthfully present the assets, financial position and performance of a particular entity" (Todorović, 2012, p. 107). Certain accounting policies should be applied for a longer period, in order to compare financial statements, and their change may be conditioned by "requirements of amended international standards, changes in legislation or management assessment, so that different accounting policies contribute to a more objective presentation of a balance sheet position" (Todorovic, 2012, p. 107).

\section{Accounting policies and their impact on the size of balance sheet positions of companies in the corporate governance system}

In this paper, we performed an analysis of applied accounting policies in companies in the Republic of Serbia, which were divided into two groups, namely companies that have subsidiaries (i.e., that consolidate) and companies that do not have subsidiaries (i.e., do not consolidate). The analysis included an assessment of the impact of applied accounting policies in the areas of intangible assets, real estate, plant and equipment, depreciation, long-term and short-term financial investments and receivables, inventories, capital and income taxes. Differences in the applied accounting policies 
in these areas have led to differences in individual balance sheet items shown in the financial statements of the analyzed groups of companies for 2018.

The collection of primary data was performed using the survey method, the questionnaire technique, which was sent by e-mail. The research was conducted during January and February 2019. The questionnaire was sent to 120 addresses of companies in the Republic of Serbia. The answer came from 49 companies, which represent the sample on which this analysis was done. For the needs of statistical analysis, the software SPSS version 2017 was used (Sheskin, 2004, Tenjević, 2002, Pallant, 2011).

\subsection{Differences in balance sheet items depending on the applied accounting policies}

In order to compare companies that have subsidiaries (or belong to the group that performs consolidation) with companies that do not have subsidiaries (or do not belong to the group that performs consolidation) by balance sheet positions of companies, $t$ test for independent samples was used. The independent variable is the answer to the question: "Does the company have subsidiaries or does it belong to a group that performs consolidation?". Dependent variables are: tangible assets, total inventories, total receivables, long-term provisions, gross profit, deferred tax assets and net profit of the company stated in the financial report for 2018.

Table 1. Results of t-test

\begin{tabular}{|c|c|c|c|c|c|c|c|c|}
\hline $\begin{array}{l}\text { Does the company } \\
\text { have a dependent } \\
\text { company or does } \\
\text { belong to a group } \\
\text { which performs } \\
\text { consolidation? }\end{array}$ & & $\mathrm{N}$ & M & SD & $\mathrm{t}$ & df & $\mathrm{p}$ & $\eta^{2}$ \\
\hline $\begin{array}{l}\text { Tangible } \\
\text { assets }\end{array}$ & $\begin{array}{l}\text { Yes } \\
\text { No }\end{array}$ & $\begin{array}{l}13 \\
36\end{array}$ & $\begin{array}{l}1032023.538 \\
3123408.944 \\
\end{array}$ & $\begin{array}{l}1920693.074 \\
17208000.990\end{array}$ & -0.434 & 47 & 0.666 & 0.004 \\
\hline $\begin{array}{l}\text { Total } \\
\text { inventories }\end{array}$ & $\begin{array}{l}\text { Yes } \\
\text { No }\end{array}$ & $\begin{array}{l}13 \\
36\end{array}$ & $\begin{array}{l}205987.077 \\
441967.444\end{array}$ & $\begin{array}{l}230949.935 \\
1755254.269\end{array}$ & -0.480 & 47 & 0.633 & 0.005 \\
\hline $\begin{array}{l}\text { Total } \\
\text { receivables }\end{array}$ & $\begin{array}{l}\text { Yes } \\
\text { No }\end{array}$ & $\begin{array}{l}13 \\
36\end{array}$ & $\begin{array}{l}361506.923 \\
555498.389\end{array}$ & $\begin{array}{l}708965.519 \\
2382533.844\end{array}$ & -0.287 & 47 & 0.775 & 0.002 \\
\hline $\begin{array}{l}\text { Long-term } \\
\text { provision }\end{array}$ & $\begin{array}{l}\text { Yes } \\
\text { No }\end{array}$ & $\begin{array}{l}13 \\
36\end{array}$ & $\begin{array}{l}9129.923 \\
6706.944\end{array}$ & $\begin{array}{l}25871.380 \\
20771.634\end{array}$ & 0.338 & 47 & 0.737 & 0.002 \\
\hline Gross profit & $\begin{array}{l}\text { Yes } \\
\text { No }\end{array}$ & $\begin{array}{l}13 \\
36 \\
\end{array}$ & $\begin{array}{l}235790.615 \\
171797.389\end{array}$ & $\begin{array}{l}588029.445 \\
620869.347\end{array}$ & 0.323 & 47 & 0.748 & 0.002 \\
\hline $\begin{array}{l}\text { Deferred tax } \\
\text { assets }\end{array}$ & $\begin{array}{l}\text { Yes } \\
\text { No }\end{array}$ & $\begin{array}{l}13 \\
36\end{array}$ & $\begin{array}{l}9371.308 \\
73.194\end{array}$ & $\begin{array}{l}23765.344 \\
231.509\end{array}$ & 1.411 & 12.00 & 0.184 & 0.041 \\
\hline Net profit & $\begin{array}{l}\text { Yes } \\
\text { No }\end{array}$ & $\begin{array}{l}13 \\
36 \\
\end{array}$ & $\begin{array}{l}204712.308 \\
149290.000 \\
\end{array}$ & \begin{tabular}{|l}
520013.963 \\
519295.901 \\
\end{tabular} & 0.330 & 47 & 0.743 & 0.002 \\
\hline
\end{tabular}

Source: Authors calculation

Companies that do not have subsidiaries have larger tangible assets $(M=3123408.94$; $\mathrm{SD}=17208000.99)$ compared to companies that have subsidiaries $(\mathrm{M}=1032023.54$; $\mathrm{SD}=1920693.07)$. The observed differences are not significant, $\mathrm{t}(47)=-0.43 ; \mathrm{p}=0.67$. The magnitude of the effect is small, $\eta^{2}=0.00$. 
Accounting policies in corporate governance practice and their impact on the financial position and business performance of company

Companies that do not have subsidiaries have higher total inventories ( $M=441967.44$; $\mathrm{SD}=1755254.27)$ compared to companies that have subsidiaries $(\mathrm{M}=205987.08$; $\mathrm{SD}=230949.94)$. The observed differences are not significant, $\mathrm{t}(47)=-0.48 ; \mathrm{p}=0.63$. The magnitude of the effect is small, $\eta^{2}=0.01$.

Companies that do not have subsidiaries have higher total receivables ( $M=555498.39$; $\mathrm{SD}=2382533.84)$ compared to companies that have subsidiaries $(\mathrm{M}=361506.92$; $\mathrm{SD}=708965.52)$. The observed differences are not significant, $\mathrm{t}(47)=-0.29 ; \mathrm{p}=0.78$. The magnitude of the effect is small, $\eta^{2}=0.00$.

Companies that do not have subsidiaries have less long-term provisions ( $M=6706.94$; $\mathrm{SD}=20771.63)$ compared to companies that have subsidiaries $(M=9129.92$; $\mathrm{SD}=25871.38$ ). The observed differences are not significant, $\mathrm{t}(47)=0.34 ; \mathrm{p}=0.74$. The magnitude of the effect is small, $\eta^{2}=0.00$.

Companies that do not have subsidiaries have lower gross profit $(\mathrm{M}=171797.39$; $\mathrm{SD}=620869.35)$ compared to companies that have subsidiaries $(\mathrm{M}=235790.62$; $\mathrm{SD}=588029.45)$. The observed differences are not significant, $t(47)=0.24 ; \mathrm{p}=0.75$. The magnitude of the effect is small, $\eta^{2}=0.00$.

Companies that do not have subsidiaries have less deferred tax Msets ( $M=73.19$; $\mathrm{SD}=231.51)$ compared to companies that have subsidiaries ( $M=9371.31$; $\mathrm{SD}=23765.34)$. The observed differences are not significant, $\mathrm{t}(12)=1.41 ; \mathrm{p}=0.18$. The magnitude of the effect is small, $\eta^{2}=0.04$.

Companies that do not have subsidiaries have lower net profit ( $M=149290.00$; $\mathrm{SD}=519295.90)$ compared to companies that have subsidiaries $(\mathrm{M}=204712.31$; $\mathrm{SD}=520013.96)$. The observed differences are not significant, $\mathrm{t}(47)=0.33 ; \mathrm{p}=0.74$. The magnitude of the effect is small, $\eta^{2}=0.00$.

\section{Conclusion}

The primary objective of financial statements is, above all, to provide financial information about the reporting entity that is critical to a large number of internal and external users. The presented information must be relevant and reliable, i.e., in the right way to present the business of a particular entity, i.e., its financial position, cash flows, changes in capital, so that users are able to make adequate business decisions. Therefore, a number of methods and procedures are included in the preparation of the financial statements, which have different effects on the reported amounts in the financial statements. The set of methods and procedures that regulate the manner of compiling and presenting financial statements fall within the domain of accounting policies. The quality of an entity's reporting system depends on the accounting policies chosen. They regulate the manner in which the reporting entity prepares its financial statements.

The involvement of employees in important functions in the company is necessary in the process of adopting accounting policies, but the main responsibility lies with the 
company's management, which makes the decision on how to assess materially significant balance sheet items. The choice of accounting policies should always be based on the set higher goals of the company's business policy. The correct choice of accounting policies by the management can greatly influence the financial position and business performance of the company.

The subject of this research was accounting policies as part of managerial decisions, but also as a means of presenting the achieved performance of the company. The analysis indicated that the applied accounting policies of companies that perform consolidation and companies that do not perform consolidation, lead to differences in the size of individual balance sheet items shown in the financial statements of these two groups of companies. Namely, the research showed that companies that do not consolidate (i.e., do not have subsidiaries) have larger tangible assets, inventories and total receivables. Unlike them, consolidating companies have higher long-term provisions, gross profit, deferred tax assets, as well as higher net profit.

\section{Reference}

Britton, A., \& Waterston, C. (2006). Financial accounting. Pearson Education. Brkanić, V. (2002). Optimizacija bilansne strukture. RRRF Plus.

International Financial Reporting Standards Foundation. (2017). IAS 8 Accounting Policies, Changes in Accounting Estimates and Errors. https://www.iasplus.com/en/standards/ias/ias8

Medojević, M. (2005). Finansijsko računovodstvo. Beogradska poslovna škola.

Međunarodni standardi finansijskog izveštavanja (IFRS). (2009). IAS 1-Prezentacija finansijskih izveštaja. Savez računovođa i revizora Srbije.

Međunarodni računovodstveni standard - MRS 8 Računovodstvene politike, promene računovodstvenih procena i greške. (2010). Službeni glasnik $R S$, br. 77/2010.

Mitrović, S. (2013). Institucionalni regulatorni okvir kao uslov kvaliteta finansijskog izveštavanja u Srbiji. U: Škobić, P. (Ured.). Zbornik radova 44. Simpozijuma Računovodstveno regulatorno okruženje: podsticaj ili ograničenje privrednog rasta (str. 60-84). Beograd: Savez računovođa i revizora Srbije.

Pallant, J. (2011). SPSS Survival manual. $4^{\text {rd }}$ edition. Allen \& Unwin.

Petrović, Z. (2011). Finansijsko izveštavanje. Univerzitet Sigidunum.

Sheskin, D. (2004). Handbook of Parametric and Nonparametric Statistical Procedures. $3^{\text {rd }}$ edition. Library of Congres

Tenjević, L. (2002). Statistika u psihologiji - priručnik. Centar za primenjenu psihologiju.

Todorović, Z. (2012). Uticaj računovodstvene regulative na spoznaju ekonomskofinansijske krize. U: Škobić, P. (Ured.). Zbornik radova 43. Simpozijuma Ekonomsko-finansijska kriza i računovodstveni sistem (str. 94-120). Beograd: Savez računovođa i revizora Srbije.

Žager, K. \& Žager, L. (1999). Analiza financijskih izvještaja. Masmedia.

Received: 16 November, 2021; Revised: 26 December, 2021; Accepted: 28 December, 2021. Rad je primljen: 16.11.2021; Korigovan: 26.12.2021; Prihvaćen: 28.12.2021. 